\title{
POTESTAS GLADII IN JESUS' TRIAL
}

The question of potestas gladii in Jesus' trial, i.e., who had the legal authority to put him to death has been for a long time one of the puzzles of the New Testament scholarship. The present article resolves the question with a balanced view that even if the ultimate potestas gladii belonged to the Roman procurator, the Jewish Sanhedrin possessed the right to condemn and execute Jesus to death on charges of the Temple offences and blasphemous utterances. However, Jesus' activity encompassed more than just a religious threat. The Jewish representatives feared also a public tumult and uprising if they had tried to put Jesus to death by themselves. They also did not want to be publicly blamed by the masses for killing a prophet type of a person and thereby adding to their negative public reputation. Therefore they handed Jesus to Pilate even though they could execute him by themselves on the basis of blasphemy.

Keywords: Potestas gladii, Jesus' trial, Pontius Pilate, Sanhedrin.

\section{Introduction}

Jesus' trial before the Jewish Sanhedrin and Pontius Pilatus presents numerous puzzles for the New Testament scholarship (Mk 14:53-15:15; par.). One of the puzzling issues revolves around the so called potestas or ius gladii, literally "the right of the sword". The phrase encapsulates the legal authority to supreme jurisdiction, i.e., the right to absolve from, or condemn a person to death. The Jews in Palestine in the times of Jesus of Nazareth (first half of the $1^{\text {st }}$ century CE) were under the rule of the Roman Empire. Their governing body (the Sanhedrin with the high priest in the lead) was not independent in its decisions and sentences and had to report to the Roman procurator - the representative of the Roman rule. This double type of rule is reflected at Jesus' trial who as a victim faced both sides: the Jewish first and then the Roman.

It is indeed this double rule status that historically makes the decision about judicial and moral responsibility regarding Jesus' death an uneasy one. It is beyond doubt that ultimately Jesus was put to death by the Roman procurator Pontius Pilatus who condemned him to crucifixion that was executed the very same day outside Jerusalem. This historical anchor of the Christian gospel and creed (see for example Valco [1] for a theological discussion) is strongly supported not only by the Gospel writers (Mk 15:15 and par.) but also by the ancient sources outside of the New Testament (the Jewish historian Josephus Flavius writes in Ant. 18,3,3 (§§ 63-64) "He was (the) Christ; and when Pilate, at

\footnotetext{
* Adrian Kacian

Department of Religious Studies, Faculty of Humanities, University of Zilina, Slovakia

E-mail: adrian.kacian@gmail.com
}

the suggestion of the principal men amongst us, had condemned him to the cross ..." [2]; ${ }^{1}$ the Roman historian Tacitus, Annals 15.44: "Christus, ..., suffered the extreme penalty during the reign of Tiberius at the hands of one our procurators, Pontius Pilatus..." [3]). But what role was played by the Jewish representatives? Did they have to deliver Jesus to Pilate because they could not sentence him to death? In other words, did the Jewish Sanhedrin hold the potestas gladii under the Roman rule or not?

The aim of the present paper is to answer the above posed questions and investigate whether the Jewish Sanhedrin in the times of Jesus had the potestas gladii in general and in Jesus' case particular. The proposed investigation will primarily throw light into the historical realms regarding Jesus of Nazareth particularly the end of his public carrier. It is evident that a more profound understanding of the historical context of Jesus' death secures a better understanding of the message of the Gospels. Secondarily, it might contribute to the Jewish-Christian dialog stigmatized in past by the propaganda that the Jews as the nation were guilty of Jesus' murder. Bearing in mind problematic history of Christian-Jewish relationship and especially the Nazism holocaust in the $20^{\text {th }}$ century, it is an imperative to access the historical data a fresh and not read the Scripture as a proof text to authorize a certain ideology (For more info see [4 - 5]).

As R. E. Brown [6] wrote, the history of research of the potestas gladii issue "altered from one extreme to the other." At the beginning, scholars like Leitzmann [7], Horvath [8] and Winter [9] and others argued that the Sanhedrin had indeed legal

\footnotetext{
According to the scholarly consensus, the final version of this text is an outcome of Christian redaction (Testimonium Flavianum). However, it is beyond doubts that Josephus' original contained the basic message of Jesus existence and his death under Pilate.
} 
authority to carry out the death sentence. The fact that Jesus was executed by the Roman authorities proves that the Jewish Sanhedrin was not involved in the trial and the Gospels as sources are historically not reliable. Later, scholars like Blinzler [10], Bock [11], Catchpole [12], Gnilka [13], Jeremias [14], Lapide [15], Matera [16], Schubert [17], Flusser [18], just to mention few, challenged this view and argued that under the Roman prefecture only the Roman procurator had the power to apply the capital sentence. Variety of above mentioned opinions reflect the given ambiguity of the primary sources that are relevant to the potestas gladii issue. In the following lines we will turn to them and investigate them.

\section{Primary sources for the potestas gladii issue}

The texts under the consideration come from three sources: the New Testament, the Jewish writers of the $1^{\text {st }}$ century CE. Josephus Flavius and Philo of Alexandria, and Mishnah. Even though the Mishnah was redacted sometimes at the beginning of the $3^{\text {rd }}$ century $\mathrm{CE}$, the material often comes from the earlier period as it is the case with the text M Sanh 7:2 that is used in this article.

The view that the Jewish Sanhedrin did not hold the competence of the capital punishment is mainly based on the two following witnesses. The first comes from the New Testament, particularly the Gospel according to John. The verbal interchange between the representatives of the Sanhedrin and Pontius Pilate over the arrested Jesus is recorded as follows: "Pilate said to them (the Jewish representatives), "Take him yourselves and judge him according to your law!" The Jews replied, "We are not permitted to put anyone to death" (Jn 18:31). ${ }^{2}$ The statement reflects the existence of two jurisdiction systems that applied to Jesus: the Jewish law on one side and the Roman law on the other. The dialogue also reveals Pilate's hesitance to be the judge in Jesus' case. This rather unusual Pilate's behavior is mainly explained as a political defense from the evangelist perspective, who aimed to describe Jesus as innocent before the Roman law and so to show that Christians as Jesus' followers were not a threat to the Roman Empire. (For example, in one of the New Testament Apocrypha, Anaphora Pilati 7 - 9, versions A, B, Pilate is mentioned even as a witness of Jesus' crucifixion and a believer of his resurrection [19 - 20]). Even though it might be true, the dialogue over the arrested Jesus reveals also the possibility that the Jewish Sanhedrin could have had the authority to judge Jesus. This is indirectly supported also by the Gospel of Peter. In this Christian apocryphal document, the disciples are full of fear from the Jews, because right after Jesus' crucifixion they were falsely accused of the attempt to burn the Temple and their lives were at stake (GPet $15: 60,52,54)[19-20]$
The other main witness that confirms the potestas gladii exclusively to the Roman procurator comes from Josephus Flavius. During the year $6 \mathrm{CE}$, Archelaus, the son of the Herod the Great, was replaced by Roman equestrian Coponius. His etnarchy (Judea and Samaria) was reduced to a province of Syria and a direct rule of the Herodian dynasty fell into the Roman hands. Josephus writes that Coponius "was sent as a procurator, having the power of life and death put into his hands by Caesar" (Bj. 2,8,1 (\$\$117) [2]. This was true also during the reign of Pontius Pilatus (26-36 CE.) who executed Jesus of Nazareth. Such juridical situation was common in the imperial provinces like Syria and particularly in its subdivision. It reflected the dominance of the Roman Empire rule over the subdued nations and countries. Pilate showed his dominion for example, by keeping the Jewish high priest's vestments under his custody. When Pilate lost his prefecture in $36 \mathrm{CE}$, the vestments after proper purification returned back in to the Temple under the seal of the priests (Ant. 18,4,2 ( $\$$ 88-95) [2].

Although the two above cited ancient sources portrait the Roman procurator as the omnipotent ruler over the life and death in his province, the actual status quo was not as definite as it might look like prima facie. The same sources also betray that the Jewish representatives (mainly high priests, Jewish nobility - persons who were members of the Sadducees party) had considerable power to influence the political affairs in Palestine under the Roman prefecture. Josephus and Philo mention several Pilate's actions that provoked the Jews. (Josephus mentions three incidents: bringing imperial standards with the emperor's portrait into Jerusalem (Bj. 2,9,2 ( $§ 169-174)$; Ant. 18,3,1 (§§ 55-59); seizing sacred funds from the Temple to build an aqueduct ( $\mathrm{Bj}$. 2,9,3 ( $\S 172-174)$; Ant. 18,3,2 ( $\S 60-62$ ); killing Samaritans at the Mount Gerizim (Ant. 18,4,1 (§§ 85-89) [2]; Philo mentions one: setting up the gilded votive shields of the emperor in the former palace of Herod the Great in Jerusalem (De Legationem ad Gaium XXXVIII. (\$§ 299-305) [21]). Three of the four above listed reports involved the Jewish or Samaritan representatives and in all these three cases Pilate had to adjust or change his decisions and actions due to the pressure from the Jewish or Samaritan nobility [19]. Moreover, following the Samaritan complaints, Pilate was ordered to report to the emperor and was replaced by Marcellus. These incidents demonstrate that the local representatives' opinion had to be respected by the Roman procurator and they even had power to orchestrate his dismissal.

In addition to the texts that confirm the power of the Roman procurator over the death sentences, there are also texts in which the Jewish local representatives play the major role over the capital penalty. In Jn 8:1-11 we read that the scribes and the Pharisees brought an adulterous woman to Jesus. According to the law of Moses she was supposed to be stoned to death (Lev 20:10; Deut 22:23-24) and they wanted to find Jesus' opinion.

${ }^{2}$ English Bible quotations, used in this paper, follow the New Revised Standard Version. 
Although the historicity of this account is questioned and the narrative's objective is to portrait Jesus as the proper interpreter of the Mosaic Law, nevertheless, this story contributes also to the potestas gladii issue. Firstly, it confirms that Jesus was ultimately executed by the Roman procurator, since the Jewish death penalty execution according to the Jewish Bible and later Mishnah, Sanh 7:1 involved stoning, burning, beheading and strangling but not crucifixion. Although in the Temple Scroll (11QMiqdash) 64:7-13 [22] the ascetic religious community that lived in Qumran expected the crucifixion as a death penalty for high treason and blasphemy [23], it is highly improbable that this opinion of a minor sect could have make its way to the ruling representatives of the Jewish nation. Secondly, the adulterous woman account displays the strong validity of the Jewish law that was inherent in the Jewish society. Jewish representatives were the first instances especially in the religion related cases and it is not too far from the truth to state that the Roman procurator did not have to know or even care about every transgression against the Jewish law (see for example, Galio's reaction to the apostle Paul case, Acts 18:12-16).

The Jewish autonomy in religious cases including the capital punishment is explicitly demonstrated in Mishna Sanh 7:2 [24]. In this text we read about an event that happened sometimes in the last 10 years of the Jerusalem Temple before its destruction in 70 CE. The Sages reported that the Rabbi Eleazar ben Zadok as a child witnessed an execution of a priest's daughter who was burnt at the stake because she committed adultery. The discussion follows stating that the way she was burnt did not follow the customs of the Pharisees (the Pharisaic way of execution would probably prefer strangulation) therefore the Mishna concludes that the court at that time was not properly trained. The dating of the event is not secured. Jeremias puts it into the reign of the Herod Agrippa I. (41-44 CE) who for period of time replaced the Roman procurators in Judea and Samaria [14]. However, more probable dating falls into years $62-63$ during the prefecture of Festus and Albinus [6]. In this case it demonstrates that the Jewish Sanhedrin possessed authority for capital punishment under the rule of a Roman procurator in the area of religious cases. The text does not mention the involvement of any higher official so we do not know whether a Roman procurator possibly knew about this death sentence or not.

Another example of Jewish autonomy in religious cases comes from the so called Temple ban. Three texts of Josephus (Ant. 15,11,5 (§417); Bj. 5,5,2 (§§193-194); 6,2,4 (§§124-126) [2] and one from Philo (Ad Gaium XXXI. (\$212) [21] describe the warning for foreigners not to step from the outer court of the Gentiles into the inner court of the Temple "under pain of death" (Ant 15,11,5 (\$417). The zeal of Jews to keep the inner court clean of the Gentiles is demonstrated, for example, in Acts 21:27-36 where they intended to kill apostle Paul, a Jew himself, because according to them he brought the Greeks into the inner court of the Temple. The fact that the Jewish representatives got this authority with the agreement of the Roman Empire is clearly witnessed by the words Titus addressed to the revolting Jews in Josephus: "Have not we given you leave to kill such as go beyond it, though he were a Roman?" (Ant. 6:126). It was an extraordinary concession as Gnilka [13] writes, but real and without need for further consulting with the Romans, as he thinks. It is more plausible to understand it as another expression of Jewish religious autonomy where the Romans did not interfere.

The evangelist Luke reports in Acts 12:1-5 how the king Herod Agrippa I. (41-44 CE) had beheaded the apostle James, brother of John the Zebedee. This example does not correspond to the Sanhedrin - Pilate interchange over Jesus since the Herod Agrippa I. as a Jew was the ruler of the Jews who replaced the rule of the Roman procurators for a while. The text does not explicitly state the reason for James' death. We can guess that it was connected with his missionary work spreading the Christian gospel that did not please the majority of the Jews including the Jewish representatives who actually opposed it. Herod Agrippa I., a Jew himself, fell into this category and used his right in agreement with the representatives of the Sanhedrin. With all the probability the case was religious but since a Roman procurator is missing in the picture, this case does not directly apply to our debate.

Another capital punishment authorized by the Jews only is described by Josephus in Ant. 20,9,1 (\$\$200-203) [2]. He tells us how James, the brother of Jesus was stoned due to the decision of the high priest Annus and "the sanhedrin of judges" because he broke the Jewish law. Josephus clearly states that the killing happened in a short time span of no procurator present in Palestine, after the death of the procurator Festus (62 CE) and before the new procurator Albinus arrived. The report goes on that "the most equitable of the citizens" disliked this decision and complained to the Herod Agrippa II. and later to Albinus himself who was on his journey from Alexandria. It seems that the reasons for complaining to Agrippa II. and Albinus were different. While the former had to do with the Jewish law that Annus broke, the latter is reported as follows: "it was not lawful for Annus to assemble a Sanhedrin without his (Albinus) consent". Albinus endorsed this reason and ultimately Annus was removed from the office of the high priest. This instance shows clearly the control of the Roman procurator over the Sanhedrin decision in the area of capital punishment. On the other hand, it has to be kept in mind that all the opposition against Annus and his decision begun because he broke the Jewish law putting James to death. Probably James and his case was not worth of capital punishment from the perspective of some respected Jews (or the part of the Sanhedrin?), who tried to stop Annus with whatever help they could find. We can only speculate whether the case would have come to Albinus, if Annus and the Sanhedrin had done everything according to the Jewish law and were unanimous with their decision.

Albinus as a Roman procurator plays an important role in an incident with a man called Jesus, the son of Ananus. Josephus (Bj. 
$6,5,3$ ( $\$ \$ 301-309)[2]$ writes that this Jesus was walking around the city of Jerusalem announcing the doom of the city and the Temple in a prophetic way. First he was brought before the "the most eminent Jews" (probably the Sanhedrin?) who then sent him to Albinus. Albinus after examination that included a severe torture came to a conclusion that this man was insane because he answered nothing to all the questions but was instantly repeating the single phrase "Woe, woe to Jerusalem!" The story confirms that Albinus exercised control over the Sanhedrin decisions as it was seen at the case of James, the brother of the Christ. Moreover, it tells us that Jesus ben Ananus was not a religious law breaker and his activity cased turmoil more in the political realm. Therefore it was natural for Albinus to take the lead in this case.

The final text under the investigation comes for the New Testament and describes the activity, process and stoning of Stephen, the first Christian martyr (Acts 6:8-7:60). His mission caught the attention of the Jews, he was brought before the Sanhedrin (Acts 6:15; Greek original synedrion) and accused of speaking blasphemous words against the Temple and the Law (Acts 6:14). After the high priest question: "Are these things so?" (Acts 7:1) Stephen offered a long speech that enraged the hearers and resulted in Stephen's execution by stoning outside of Jerusalem city limits. Stephen's process resembles similarities with the one of Jesus of Nazareth, especially the Markan version [25]. Several scholars [13, 19 and 26] regard this incident as an example of a lynch law without a trial. Hence it does not give a clue regarding the Sanhedrin's right to issue a capital sentence. On the other hand, scholars like Bruce [27] understand it as an example of the Sanhedrin's religion autonomy in the capital sentence. Stephen's speech against the Tempe could belong to the category of blasphemy and therefore the Jewish authorities did not have to consult the Roman procurator.

\section{Conclusion}

After screening all the relevant ancient sources we can offer a conclusion to the potestas gladii case during Jesus' time. The outcomes demand a more balanced view of the power of the capital punishment in the Palestine during the Pilate's procuratorship. It is clear that the right belonged primarily to the Roman procurator. It was a sign of his position as he represented the dominance on the Roman Empire. However, the actual realization of this right and duty might have varied from one procurator to the other. For example, as we saw, Albinus strictly followed this rule having a negative experience with autonomous decision of the Sanhedrin over James, the brother of the Christ during the interregnum period. Also the Jewish representatives during Albinus' term learned their lesson since they reported the case of Jesus ben Ananus to him. However, in the case of Pontius Pilate, it seems that the Jewish Sanhedrin exercised a greater autonomy even in the capital cases. The stoning of Stephen and also the Pilate's words: "Take him yourselves and judge him according to your law!" (Jn 18:31) when Jesus was brought to him, point this direction. Therefore, it is very probable to conclude that the execution of reign including potestas gladii was not unanimous with all the procurators and that the Jewish Sanhedrin could have gained more ground under a certain procurator.

It is evident that any competence of the Jewish representatives during the procuratorship was dependent on the procurator's decision. Yet, on the other hand, there were domains in which the Sanhedrin was autonomous in its sentences including even the capital one. The sources demonstrate that the religious agenda connected with the Temple (Stephen's blasphemy, breaking the Temple ban, adultery of the priest's daughter) was one of the domains that the Jewish Sanhedrin had the authority of potestas gladii. Although its reach and actual execution might vary, this limited capital authority is best to be understood as an exception in connection with the Temple and the Jewish religion. For example, the Temple tax falls also in this category that incorporated peculiarities of the Jewish religion from the Roman perspective and aimed to secure religious peace in their occupied territories. (Adultery may not seem to fit under the same cultic category with blasphemy or breaking the Temple ban, but, as Hrobon [28] points out, according to the law of Moses, it defiles not only the adulterer, but also the sanctuary of God and even the land of Israel (see, e.g., Lev 18). However, the authority was not limited only to the acts that are explicitly referred to in biblical sources as defiling).

Finally, we can state with the all probability that in Jesus' trial, the Sanhedrin had the authority to put Jesus to death, if Jesus had been guilty only on the religious terms as a blasphemer and Temple breaker (see Mk 14:53-65 and par.). However, it seems that it was more to Jesus' case than a religious accusation of a blasphemer. The Sanhedrin evaluated his activities as a threat also in the political area. He attracted big crowds, performed many signs and the Jewish representatives feared that all this could easily turn in to a riot or upraising against the Romans (see Jn 11:45-53). It has to be kept in mind that few of Jesus' actions could be interpreted along these lines, especially his words about the destruction of the Temple (Mk 13:1-2 and par.) and his cleansing of the Temple (Mk 11:1519 and par.). The leading Jews were content with the political status quo under the rule of the Romans and a possible upraising would destroy their power, wealth and status. The later Jewish war against the Romans (66-70 CE) proved this fear to be true.

The threat of a tumult caused by Jesus' execution was probably the main reason why the Sanhedrin turned to Pilate even though it did not necessarily had to. Jesus was not a marginal figure at the end of his public carrier and his activities especially during the Jewish festivals where the multitudes of Jews gathered in Jerusalem could not be overlooked. To execute him secretly was not an option for the Sanhedrin because the risk of a riot was very high as was the Pilate involvement that would immediately 
follow. In addition they would risk the anger of the multitudes having executed Jesus as a religious blasphemer. Therefore, they handed him to Pilate and presented him as a political threat to the Roman Empire. Pilate recognized the trap and wanted to escape from it via the privilegium paschale - the ancient right to release a prisoner (Mk 15:6-15 and par.). However, the Jewish leaders were a step ahead of the game and causing a public tumult (Mk 15:11) pushed Pilate to a decision he did not favor. For the Pax Romana was more important for Pilate than the truth standing in front of him.

\section{References}

[1] VALCO, M., KRALIK, R., VALCOVA, K.: From Creation to Redemption: Chapters from Lutheran Dogmatics and Christian Ethics - Part I. (In Slovak), $2^{\text {nd }}$ revised ed., KUD Apokalipsa : Ljubjlana, 2013.

[2] WHISTON, W. trans.: The Works of Josephus. Complete and Unabridged, $2^{\text {nd }}$ ed., Hendrickson : Peabody, MA, 1998.

[3] ELWELL, W. A., YARBROUGH, R. W. ed.: Readings from the First-Century World. Primary Sources for the New Testament Study, Baker : Grand Rapids, 1998.

[4] SLIVKA, D.: The Torah in the Modern Jewish Tradition, Acta Univeritatis Palackianae Olomucensis, 2012, 13, 53.

[5] SORYS, S.: Rights of Freedom in the Social Teaching of the Church (in Poland), Prace naukowe Chrzanow, Wyzsa Szkola Przedsiebiorczosci i Marketingu, 2009.

[6] BROWN, R. E.: The Death of the Messiah. From Gethsemane to the Grave, vol. 1, Doubleday : New York, 1994.

[7] LIETZMANN, H.: Bemerkungen zum Prozess Jesu, Zeitschrift fur die Neutestamentliche Wissenschaft, 1931, 30, 211.

[8] HORVATH, T.: Why was Jesus brought to Pilate, Novum Testamentum 1969, 11, 174.

[9] WINTER, P.: On the Trial of Jesus, Walter de Gruyter, Berlin, 1961.

[10] BLINZLER, J.: Der Prozess Jesu, $4^{\text {th }}$ ed., Pustet : Regensburg, 1969.

[11] BOCK, D. L.: Blasphemy and the Jewish examination of Jesus, Bulletin for Biblical Research, 2007, 17, 53.

[12] CATCHPOLE, D. R.: The Trial of Jesus, Brill : Leiden, 1971.

[13] GNILKA, J.: Jesus of Nazareth: Message and History (orig. Jesus von Nazaret, Botschaft und Geschichte,1993), Hendrickson : Peabody, MA, 1997.

[14] JEREMIAS, J.: Zur Geschichtlichkeit der Verhors Jesu vor dem Hohen Rat, Zeitschrift fur die Neutestamentliche Wissenschaft, 1950-51, 43, 145.

[15] LAPIDE, P.: Wer War Schuld an Jesu Tod? (1987), CDK : Brno, 1997.

[16] MATERA, F. J.: The Trial of Jesus: Problems and Proposals, Interpretation, 1991, 45, 5.

[17] SCHUBERT, K,: Jesus im Lichte der Religionsgeschichte des Judentum, Wien : Herold Verlag, 1973.

[18] FLUSSER D.: Jesus, Jerusalem : The Hebrew University Magnes Press, 1998.

[19] DUBOVSKY, P. ed.: Mark: Commentaries to the New Testament (in Slovak), Dobra kniha : Trnava, 2013.

[20] KORECKOVA, A.: Apocryphal Tradition in the Gospel According to Mark, Testimonium Fidei, 2014, to be published.

[21] YONGE, C. D. trans.: The Works of Philo. Complete and Unabridged. New Updated Version, $4^{\text {th }}$ ed., Hendrickson: Peabody, MA, 1997.

[22] GARCIA MARTINEZ, F. trans.: The Dead Sea Scrolls Translated: The Qumran Texts in English, $2^{\text {nd }}$ ed., Eerdmans/E. J. Brill: Grand Rapids : Mi/ Leiden, 1996.

[23] BETZ, O.: The Temple Scroll and the Trial of Jesus, Southwestern J. of Theology 1988, 30, 5.

[24] DANBY, H. trans.: The Mishnah, Oxford University Press : London, 1933.

[25] WITHERINGTON, B. III: The Acts of the Apostles. A Socio-Rhetorical Commentary, Eerdmans : Grand Rapids, Mi, 1998.

[26] PESCH, R.: Die Apostelgeschichte I, Neukirchener : Neukirchen-Vlynn, 1986.

[27] BRUCE, F. F.: The Book of the Acts, revised ed., Eerdmans: Grand Rapids, Mi, 1988.

[28] HROBON, B.: Ethical Dimension of Cult in the Book of Isaiah, De Gruyter, Berlin, New York, 2010. 